Espen O. Henriksen er førsteamanuensis i naturfag og har vært ansatt ved Institutt for lærerutdanning og kulturfag,

Høgskolen i Bod $\varnothing$, siden 2000. Interesseområdet er tilpasset opplæring i naturfag. Han har tidligere jobbet i Norsk

Polarinstitutt med problemstillinger knyttet til miljøgifter i nordområdene.

\title{
Rollespill og Teaching Thinking som redskaper for aktiv læring i naturfag - erfaringer fra allmenn- lærerutdanninga
}

\begin{abstract}
Teaching Thinking (teaching strategies developed by Thinking Skills Research Group, University of Newcastle) and role-play were used in a science course at a teacher's college and evaluated by the students. The experiences are discussed with reference to democratic participation as the most important aim for compulsory science education. It is argued that role-play and Teaching Thinking-strategies give students and pupils in science classes motivation and opportunities to communicate on science issues at their own skill level. This kind of communication has several merits: i) It reveals some of the students' alternative conceptions; ii) it enforces content learning; and iii) it supports the development of skills needed for democratic participation.
\end{abstract}

\section{INNLEDNING}

Det har lenge vært en alminnelig oppfatning at aktivitet er en forutsetning for god læring. Aktivitetspedagogikken har røtter helt tilbake til Aristoteles, men har i nyere tid først og fremst blitt assosiert med John Dewey (se f.eks. Imsen, 1999). Slagordet "Learning by doing" er velkjent. I nyere tid har dette synet blitt mer nyansert, og da ikke minst gjennom utviklingen av naturfagenes didaktikk. Driver (1983, s. 9) antyder at elevopplevelsen i en del aktivitetsbaserte opplegg bedre kan beskrives med: "I do and I am even more confused". Aktivitet er altså ikke tilstrekkelig for å oppnå læring.

I naturfag er praktiske aktiviteter en viktig del av selve faget (Turmo, 1999). Naturvitenskapens prosesser (det vil si metoder, teknikker og prosedyrer) regnes som en av tre grunnleggende dimensjoner i naturfaget (Sjøberg, 2004). Ekskursjonen, og ikke minst elevforsøket, er arbeidsformer som har som mål å ivareta denne delen av faget. Turmo (1999) antyder at argumenter om vitenskapens vesen og argumenter om effektiv læring har blitt sammenblandet. Det er jo ikke sikkert at den typen aktivitet som ligger nærmest naturforskerens arbeidsmåte er den aktiviteten som gir best læring. Imsen (1999) gir et slående eksempel på hvordan naturfagforsøk gjennomføres etter gitt oppskrift i en kontekst der evnen til selvstendig tenkning nærmest er koblet ut. I en praksisfortelling med tittel "Koker det nå, lærer?" får vi høre hvordan dyktige 7.klassinger er avhengig av lærerens bekreftelse for å notere at fosskokende vann har nådd kokepunktet.

Kanskje har elevforsøk og ekskursjoner vært naturfagenes alibi i forhold til aktiv læring? Etter å ha aktivisert elevene med elevforsøk kan naturfaglæreren tenke at nå har elevene vært aktive, og nå må resten av undervisningstiden brukes til å formidle begrepene og lovmessighetene. Man vil jo sikre at elevene skal ha muligheter til å forstå hva de gjorde i forrige eller neste elevforsøk. Nå er 
det ikke gitt at elevforsøk alltid skal foregå etter gitt oppskrift, men det kan være grunn til å tro at dette har vært det vanligste. For kjemiaktiviteter er dette dokumentert av Ringnes og Hannisdal (2000). De undersøkte et utvalg kjemiaktiviteter i læreverk for grunnskole og videregående skole sett i lys av Anderssons fire frihetsgrader for aktiviteter/praktisk arbeid (Andersson, 1989) og fant at de aller fleste aktivitetene hadde null eller én frihetsgrad.

Det er ikke uvanlig at naturfagklasserom domineres av at lærer presenterer fagstoff og forteller elevene hva de skal gjøre av praktiske aktiviteter (Mortimer \& Scott, 2003). Elevenes mulighet for ytringer begrenses gjerne til å bekrefte den naturvitenskapelige historien som lærer ønsker å formidle. Mortimer og Scott (2003) påpeker at en mer dialogisk tilnærming er nødvendig for at elevene skal få anledning til å bygge opp sin forståelse. Wellington og Osborne (2001) legger vekt på at læring av naturvitenskap innebærer å lære et fagspråk. Enhver språkopplæring krever at den lærende får delta i muntlig dialog og bygge opp egne resonnementer der de nye ordene tas aktivt i bruk.

I dette arbeidet ønsket jeg å utforske potensialet til to elevaktive tilnærmingsmåter som kan fremme dialog og begrepsutvikling, nærmere bestemt arbeidsmåtene rollespill og Teaching Thinking-metodikk. Disse arbeidsmåtene ble utprøvd i egen praksis med undervisning av allmennlærerstudenter i faget Natur, samfunn og miljø. I og med at utprøvingen ble gjennomført i en lærerutdanning ble det naturlig med en todelt problemstilling:

1) Hvilket potensiale har arbeidsmåtene rollespill og Teaching Thinking for begrepsutvikling i naturfag generelt?

2) Er arbeidsmåtene rollespill og Teaching Thinking egnet som eksemplarisk undervisning i lærerutdanninga?

Jeg vil drøfte disse problemstillingene ut fra teoretiske betraktninger, observasjoner av lærerstudenter som deltok i utprøving av arbeidsmåtene og en spørreundersøkelse blant de samme lærerstudentene.

\section{BAKGRUNN FOR DE ARBEIDSMÅTENE SOM BLE UTPRøVD}

\section{Rollespill}

Rollespill i undervisningssammenheng er nærmere beskrevet av Bjørshol (1994). Han trekker fram noen grunnleggende elementer som vanligvis kjennetegner rollespill i klasserommet (s. 9):

1. Eleven bytter rolle fra den dagligdagse i et elev-lærer-forhold til en fiktiv rolle i en situasjon gitt av lærer eller medelev. Den fiktive rollen vil som oftest være svært forskjellig fra den personlige.

2. Formålet med et rollespill vil være å dramatisere en bestemt episode eller samfunnsmessig situasjon.

3. Vanligvis er det ikke noe publikum til rollespillet, da hele klassen deltar. [....]

4. Det vil ikke foreligge et fast manus, men noen linjer på et ark som kan fungere som hjelp i replikkvekslingen. Elevenes improvisasjoner er i fokus. Replikkene blir fritt laget ut fra de instruksene som er gitt...[...].

5. Sceneutstyr vil som oftest ha liten betydning. Det man kan finne av rekvisitter i klasserommet brukes til å støtte fiksjonen.

Bjørshol sammenligner også klasserommet med et teater, der læreren er den skuespilleren som oftest står på scenen. Rollespill gir elevene mulighet til å komme ut av den passive tilskuerrollen.

Bjørshols momentliste (ovenfor) skulle gi en omtrentlig avgrensning for hva rollespill i undervisning dreier seg om. De naturfaglige rollespillene som tas opp her avviker imidlertid fra Bjørshols momentliste på et par punkter. Det er ikke nødvendigvis elevenes improvisasjoner som er i fokus, 
snarere kan det faglige man lærer i forberedelsen være det viktigste. Ofte kan det også være aktuelt at gruppene framfører et forberedt rollespill for lærer og medelever, og da har man jo et publikum til rollespillet.

Bjørshol (1994) mener at rollespill setter følelser og kreativitet i sving, og hevder at dette kan bidra til å inkludere barn som er dominert av høyre hjernehalvdel. Dette i motsetning til tradisjonell undervisning, som favoriserer de barna som er best trent $\mathrm{i}$ å utnytte venstre hjernehalvdels rent språklige og logiske evner. Med utgangspunkt i Blooms taksonomi (Bloom, 1956) hevder Bjørshol også at rollespill kan gi en helhetlig undervisningsmetode. Det dreier seg nemlig ikke bare om å reprodusere kunnskap, men om å anvende fagstoff inn i en sammenheng.

Det finnes flere gode argumenter for at lærerstudenter må få opplæring i å bruke rollespill som virkemiddel i fagene. Den formelle dekningen er nedfelt i L97, som er den norske statlige læreplanen for grunnskolen innført i 1997 (KUF, 1996). L97 har en egen del om prinsipper og retningslinjer for opplæringa. Her heter det: "Drama som fagområde og metode er ein del av innhaldet og arbeidsmåtane i fleire fag. Skapande verksemd, opplevingar og kreative uttrykksformer skal lyftast fram i opplæringa." Som en del av evalueringa av L97 ble det gjort en undersøkelse om bruk av drama, rettet mot lærere som underviser i norsk (Sæbø, 2003). 239 av lærerne i undersøkelsen underviste også i natur- og miljøfag. Av disse rapporterte 23 \% at de bruker drama i natur- og miljøfagundervisninga. Sæbøs undersøkelse dekket alle trinn, men når det gjelder natur- og miljøfag ble ungdomstrinnet kraftig underrepresentert fordi fagkombinasjonen norsk og naturfag er mindre vanlig på høyere klassetrinn. Sæbø konkluderer som følger i forhold til den generelle bruken av drama i opplæringa: "Undersøkelsen viser med all tydelighet at det er et manglende samsvar mellom den formelle og den gjennomførte planen." (Sæbø, 2003, s. 124). I en evaluering av natur- og miljøfag etter innføring av L97 (Almendingen, Klepaker \& Tveita, 2003) var det vanligste svaret fra elevene i 99 av 167 sjuendeklasser at rollespill eller drama var arbeidsmåter som "aldri" ble brukt. I 59 av de resterende klassene var "sjelden" det vanligste svar på samme spørsmål. "Sjelden" eller "aldri" var også svaret fra et stort flertall av lærerne for de samme sjuendeklassene. Et stort flertall av elevene (særlig jentene) og rundt halvparten av lærerne (flest blant kvinner) i samme undersøkelse har et ønske om å bruke rollespill/drama oftere (Almendingen m.fl., 2003). Tilgjengelige undersøkelser tyder altså på at drama og rollespill bør brukes oftere i norsk naturfagundervisning, og som lærerutdanner bør man derfor framheve hvordan disse arbeidsmåtene kan tas i bruk. Med den nye norske læreplanen som skal gjelde fra høsten 2006, Kunnskapsløftet, (UFD, 2005) forsvinner imidlertid delen "Prinsipper og retningslinjer for opplæringa", der man fant den mest eksplisitte instruksen om hvilke undervisningsmetoder som skal brukes. Erstatningen er den såkalte "Læringsplakaten" (UFD, 2005). Her er eksplisitt omtale av arbeidsmåter erstattet av mer generelle formuleringer om blant annet tilpasset opplæring, varierte arbeidsmåter og muligheter for alle til å utvikle sine egne læringsstrategier. For å følge opp de generelle intensjonene i "Læringsplakaten" vil det imidlertid være avgjørende at den enkelte lærer kjenner til de muligheter som ligger i forskjellige arbeidsmåter.

I "Metodisk veiledning i naturfag" fra 1989 understrekes de store mulighetene som ligger i å bruke rollespill til å "vise og forklare fenomener i naturfag" (Kvam, Størkersen \& Valdermo, 1989, s. 48). Som eksempler beskrives det hvordan elever kan gå inn i roller som hormoner, nukleotider eller atomer og etterligne forskjellige prosesser og strukturer. Tveita (2003) beskriver rollespill for undervisning om partikkelmodellen og elektriske kretser der elevene fungerer som henholdsvis partikler og elektroner. Disse arbeidene omtaler rollespill som framhever materielle/mekaniske prosesser. I kontrast til dette framhever "Metodisk veiledning" for grunnkurs i naturfag etter reformen i 1994 (Læringssenteret, n.d.) hvordan rollespill kan brukes i forbindelse med problemstillinger som tar opp normative spørsmål. Her legges det vekt på rollespill der meningsutveksling mellom mennesker er det sentrale, og dette illustreres med et eksempel om interessemotsetninger rundt bruken av et fjellområde. Kontekstualisering av faget er også sentralt for Marianne Ødegaard, som har skrevet en dr.scient-avhandling om bruk av drama i naturfagsundervisningen (Ødegaard, 
2001a, 2001b). Ødegaard finner at elevene i utgangspunktet legger vekt på de etiske problemstillingene, men "når diskusjonen blir av mer personlig og emosjonell art, øker etterspørselen av ren faktakunnskap" (Ødegaard, 2001b).

\section{Teaching thinking}

Teaching thinking (TT) er en didaktisk tilnærming som er utviklet av didaktiker og geograf David Leat og hans samarbeidspartnere ved Universitetet i Newcastle. I TT-metodikken er undervisningsøktene basert på et forråd av effektive pedagogiske strategier ("Powerful Pedagogical Strategies" - PPS) som kjennetegnes av følgende (oversatt og forkortet fra Leat \& Higgins, 2001):

1. Strategiene representerer en overkommelig mengde endring av praksis. De kan om ønskelig innføres bare i en enkelt undervisningstime. Læreren kan dermed ha kontroll over endringsprosessen.

2. Strategiene er svært fleksible i forhold til elevenes læreforutsetninger og faginnhold.

3. Oppgavene som gis har ikke fasitsvar, men noen svar vil helt klart være bedre enn andre. Den enkelte elev blir stimulert til å resonnere og bidra med sin mening.

4. Strategiene bygger på et konstruktivistisk syn på læring i og med at de stimulerer elevene til å ta i bruk det de allerede kan i nye resonnementer.

5. Strategiene fremmer diskusjon i grupper og i klassen. Informasjonen som gis er ikke entydig, tvert imot kreves det ofte tolkning, klargjøring, sammenkobling og dannelse av hypoteser. Dermed oppstår en type dialog som kan hjelpe elevene til sammen å konstruere en forståelse knyttet til oppgavens faglige innhold.

6. Strategiene leder fram til en avsluttende "debriefing" der formålet er refleksjon rundt det man eventuelt har lært gjennom TT-opplegget og økt bevisstgjøring om selve tenke- og læreprosessen (metakognisjon).

Det vil føre for langt å beskrive alle TT-strategiene her. Som eksempler vil jeg kort beskrive to av de strategiene som jeg har tatt i bruk i min egen praksis, nemlig "En må ut" og "Kart fra minnet".

Prinsippet i "En må ut" ('Odd one out') er kjent fra spill og TV-underholdning. Man blir presentert for en liten gruppe (3-4 stk.) som for eksempel kan bestå av begreper eller personer. Det gjelder så komme fram til kreative forslag som begrunner hvorfor ett av begrepene eller en av personene ikke passer sammen med de andre. Man må altså komme fram til et eller annet forhold som forener alle unntatt 'the odd one'. Elevene sitter først i små grupper og gjennomgår flere slike grupper for å finne hvem eller hva de mener bør ut. Deretter kan man ha en felles 'debriefing' og oppsummere mulige løsninger som gruppene har kommet fram til (som nevnt ovenfor bør oppgavene ha mer enn en mulig løsning). Det hevdes at denne strategien gir "muligheter for eksplorerende samtaler som gir den lyttende lærer et vindu mot elevenes egen tenkning" (TT-NOR, 2005).

"Kart fra minnet" er en slags stafett med tre-fem elever på hvert lag. Målet med stafetten er at lagene skal prøve å rekonstruere en figur som læreren har liggende på kateteret. I hver etappe får en elev fra hver gruppe komme fram til kateteret og se på figuren i ti sekunder, for så å returnere til gruppa. Mellom etappene oppdaterer gruppene sine figurer ut fra hva som ble observert. I tillegg til at man oppnår et sterkt fokus på den aktuelle figuren kan det også legges vekt på mulige strategier og samarbeid i gruppene (TT-NOR, 2005).

Strategiene ovenfor er beskrevet på nettsider tilhørende utviklingsprosjektet TT-NOR (Teaching Thinking Norway / Tren Tanken Norge) som ledes av historiker/didaktiker Erik Lund ved Høgskolen i Østfold. Formålet med dette prosjektet er å tilpasse og videreutvikle Teaching Thinkingmetodikk til norske forhold. Prosjektet er primært rettet mot samfunnsfagundervisning på grunnskolens ungdomstrinn, men har "også en tverrfaglig målsetting" (TT-NOR, 2005). Det vises til TT-NORs nettsider for beskrivelser og eksempler på anvendelser av en rekke forskjellige TT-strategier (TT-NOR, 2005). Ved Høgskolen i Bodø har samfunnsgeograf Odd Ståle Eide samlet erfa- 
ringer om bruk av TT i allmennlærerutdanningen i samfunnsfaglige sammenhenger (Eide, 2002). Eide sammenfatter også erfaringer fra lærerstudenter som har prøvd ut TT i sin studentpraksis. Disse studentene formidlet så å si utelukkende positive erfaringer med bruk av TT i grunnskolen (Eide, 2002).

Som det framgår ovenfor har Teaching Thinking gjennomgående blitt utviklet i samfunnsfagdidaktiske miljøer. Det finnes imidlertid også publiserte eksempler på anvendelser innen naturfag. Leat og Higgins (2001) viser til et eksempel om adaptive egenskaper som kreves for at dyr skal overleve i Arktis. Et norsk eksempel er Berg (2002), som har lagd et opplegg rundt nedbeitingen av tareskog.

\section{FORSKNINGSMETODE}

Utprøving av arbeidsmåtene rollespill og Teaching Thinking ble gjennomført i en klasse på 36 studenter som fulgte IKT- og samlingsbasert allmennlærerutdanning ved Høgskolen i Bodø studieåret 2002/03 (1. studieår). Utprøvingen var fordelt over tre undervisningssamlinger som en del av min undervisning i faget Natur, samfunn og miljø (NSM). NSM var på dette tidspunktet et obligatorisk fag i norsk allmennlærerutdanning. Dette innebar at studiet også ble fulgt av studenter som ikke var spesielt interessert i naturfag. I tillegg er lærerstudentenes forkunnskaper i naturfag svært variable, etter som det ikke er spesielle kompetansekrav i naturfag for å få begynne på studiet.

\section{Gjennomføring av rollespill}

Rollespill ble utprøvd i løpet av to undervisningstimer 7. februar 2003 som en del av arbeidet med å nå mål i NSMs rammeplan (KUF, 1999) relatert til økosystem/stoffkretsløp, og mål om bruk av varierte arbeidsmåter. Jeg valgte å bruke rollespill i forhold til disse målene fordi jeg mener at rollespill er velegnet til å konkretisere prosesser der flere aktører eller komponenter inngår. Samtidig kunne jeg ved eksemplarisk undervisning introdusere en elevaktiv arbeidsmåte.

Ut fra erfaringer fra tidligere forsøk på å gjennomføre rollespill om teoretisk økologi la jeg vekt på å gi studentene hjelp til å komme i gang. Det ble derfor delt ut forslag på hvordan det kan gjøres, med eksempler på mulige roller og replikker (Se eksempel i Boks 1). Erfaringen fra tidligere utprøving uten slike konkrete eksempler var at studentene fant det vanskelig å komme i gang, og produktene kunne noen ganger mangle naturfaglig relevans. Studentene ble delt i grupper der antallet i hver gruppe var tilpasset tildelt tema for rollespill. På samlingsbaserte studier er undervisningstiden svært begrenset, så det ble kun satt av en undervisningstime til introduksjon og produksjon av rollespillene, og en time til framføringer med kommentarer og diskusjon. Studentene ble rådet til ikke å ha store ambisjoner om at rollespillene skulle ha kunstnerisk verdi eller underholdningsverdi.

I forberedelsesfasen fikk studentene veiledning etter behov. De oppgitte faglige tema hadde varierende vanskelighetsgrad, og hvis jeg hadde kjent studentene bedre, kunne jeg gjort noen valg med hensyn til fordeling av lærestoff mellom gruppene. Jeg måtte presse studentene litt fordi det var liten tid og påpeke at dette var en utprøving av arbeidsmåten, og at man i grunnskolen har mulighet til å bruke noe mer tid enn vi kan gjøre i høgskolesammenheng. Etter framføring av hvert rollespill ga jeg faglige kommentarer og oppfølgingsspørsmål til studentene.

\section{Gjennomføring av Teaching Thinking-metodikk: "En må ut"}

I forbindelse med arbeid om økosystemet i fjæra og systematisering av liv lagde jeg et TT-opplegg basert på strategien "En må ut". Opplegget ble gjennomført i september 2002. Denne TT-strategien innebærer at deltakerne skal finne kriterier for hvilken som ikke passer inn i en liten gruppe. Studentene fikk i dette tilfellet utdelt et oppgaveark med ti grupper som hver inneholdt navn og bilde av fire arter (planter og/eller alger og/eller dyr). De skulle så drøfte med sine nærmeste medstudenter hvilken art som ikke passet inn i hver gruppe. Det hele ble presentert som en konkurranse 


\section{Boks 1. Eksempel på instruksjoner til et rollespill om $\emptyset$ kologi.}

Rollespillet skal være kort $(<10 \mathrm{~min}$, evt. $<5 \mathrm{~min}$ ) og ha replikker som sier noe om fagstoffet innenfor generell økologi.

\section{Tema nitrogenkretsløp}

Nitrogenets kretsløp - deltakerne er nitrogen og de forskjellige stasjonene som nitrogenet passerer

Rolle 1+2: Nitrogenatomet x 2. Eksempel på utsagn: "Jeg er nitrogenet som er så viktig for alt som lever. Ingen planter kan danne grønne blader uten meg. Ingen dyr kan ha muskler uten meg. Her i lufta går vi nitrogenatomer to og to og er frie som fuglen. Nesten ingen får tak i oss."

Rolle 3: Gresset eller bjørka: Eksempel på utsagn: "Skulle gjerne ha tak i de nitrogenatomene som flyr der borte"

Rolle 4: Oretreet (older) eller erteplanten/kløverplanten: Eksempel på utsagn: "Jeg har noen gode små venner som bor hos meg. De vet hvordan nitrogenatomparet kan fanges, splittes, og brukes hver for seg. Og når jeg dør kan andre bruke nitrogenforbindelsene etter meg, slik at flere får nytte av nitrogenet som mine små venner fanget."

Rolle 5: Lammet: Eksempel på utsagn: "Jeg liker best grønt saftig gress med mye nitrogen, for da får jeg næring til å bygge opp muskler."

Rolle 6: Rovdyret: Eksempel på utsagn: "Bare jeg får tak i et byttedyr, så får jeg tak i rikelig med nitrogen. Plantene elsker at jeg deler ut av mitt nitrogenoverskudd ved å markere litt her og der."

Rolle 7: Nedbryterbakterien. Eksempel på utsagn: "Ingen kan bruke nitrogen fra døde dyr og planter uten at jeg hjelper til."

Rolle 8: Denitrifiseringsbakterien(!). Eksempel på utsagn: "Jeg lever av å frigjøre nitrogenatomer fra andre stoffer, slik at de slipper å bli utnyttet av planter og dyr. Når jeg kobler de sammen to og to får de et langt og fritt liv som par i atmosfæren.”

om å finne fram til flest mulig faglige begrunnelser for hvilke arter som ikke passet inn. Innen feltet biologisk systematikk er det i utgangspunktet enkelt å lage et opplegg der organismer presenteres i sett på fire, hvor av tre tilhører samme taksonomiske gruppe. Imidlertid skal man i Teaching Thinking-strategiene unngå oppgaver med entydige fasitsvar, og det er også ønskelig at studentene henter fram kunnskaper utover det som er relatert til systematikk. Det ble derfor her lagt opp til at en rekke forskjellige kriterier skulle kunne gi løsninger for hvem som ikke passer inn, slik som spiselighet, bevegelighet, habitat, plass i næringskjeden, og selvfølgelig også systematisk tilhørighet. Dette er demonstrert i følgende eksempel (versjonen som ble brukt i undervisning hadde miniatyrbilder av artene og ikke latinske artsnavn):

Hare (Lepus timidus)

Kantarell (Cantharellus cibarius)

Blåskjell (Mytilus edulis)

Fjærerur (Semibalanus balanoides)

Mulige løsninger som jeg la opp til her er: i) Hare skal ut fordi den beveger seg raskt mens alle de andre organismene er fastsittende. ii) Kantarell skal ut fordi den tilhører soppriket, de andre tilhører dyreriket. iii) Fjærerur skal ut fordi den ikke er anvendelig som mat.

Studentene var tidligere introdusert til systematiske hovedgrupper i fjæra, og dette var derfor delvis en repetisjonsøvelse. Hvis denne øvelsen skulle vært en første introduksjon til systematikken måtte man satt av mer tid og utstyrt studentene med oppslagsverk slik at de kunne lete etter "systematiske løsninger". 


\section{Gjennomføring av Teaching Thinking metodikk: "Kart fra minnet"}

Denne TT-strategien brukes for å rette et sterkt fokus på en enkelt figur. Gjennomføringen fant sted i løpet av ca. en skoletime 01.11.2002. Figuren som ble brukt ved den anledningen var en egenprodusert skjematisk illustrasjon av abiotiske faktorer som er viktige for primærproduksjonen i havet (lys, næringssalter, vertikal sirkulasjon, kompensasjonsdyp). Klassen ble delt i stafettlag á fire studenter. I hver "etappe" fikk én deltaker fra hvert lag se på figuren i ti sekunder. Mellom "etappene" arbeidet lagene med sine skisser og diskuterte hvilke deler av figuren neste gruppemedlem burde fokusere på i neste etappe. Etter de fire etappene sjekket jeg hvor mye de forskjellige lagene hadde klart å få med på sine skisser. Deretter foreleste jeg om figurens faglige innhold.

\section{Observasjoner}

Observasjonene som er referert i resultatdelen er subjektive inntrykk fra egen undervisning. I mangel av video- eller lydopptak har jeg valgt å trekke fram overordnet inntrykk og noen enkeltepisoder som ble notert i etterkant av undervisninga.

\section{Spørreunders $\phi$ kelse}

Spørreundersøkelsen blant studentene ble gjennomført i april 2003, omtrent to måneder etter siste del av den aktuelle undervisninga. Det ble brukt et elektronisk spørreskjema på vårt LMS ("læreadministrerings-system") (ClassFronter). Systemets muligheter for anonyme svar og 'kun ett svar' ble brukt for å sikre at studentene skulle kunne uttale seg fritt, og for å sikre at ingen studenter kunne svare mer enn en gang. Studentene fikk e-post med en generell oppfordring om å svare. Etter som det ikke var mulig å se hvem som hadde svart ved svarfristen, ble det bare sendt ut en generell påminnelse om undersøkelsen, også denne på e-post. Skjemaet var tilgjengelig for 36 studenter. 25 svarte, noe som tilsvarer en svarprosent på 25/36 69 \%. Hovedtyngden av skjemaet bestod av 21 utsagn som studentene kunne si seg mer eller mindre enig i på en firedelt skala (helt uenig - litt uenig - litt enig - helt enig) (se tabell 2). En firedelt skala ble valgt (framfor en femdelt) for å tvinge fram svar i enten den ene eller andre retningen. Skjemaet inneholdt også spørsmål om kjønn, grad av fordypning i naturfag fra videregående skole og åpne felt med oppfordring om å skrive inn eventuelle utfyllende kommentarer.

\section{Resultater}

\section{Observasjoner fra gjennomføring av undervisninga}

Med litt veiledning og forsiktig press klarte gruppene å fullføre manus til korte rollespill i løpet av den tildelte tiden. Noe frustrasjon kom til syne fordi lærestoffet var nytt. Det var imidlertid mye humor og latter knyttet til produksjon og framføring. Innholdsmessig var det variasjon i hvor langt gruppene beveget seg fra mine veiledende eksempler. Tabell 1 gir eksempler på observerte situasjoner i rollespillene som ledet videre til drøfting av naturfaglige problemstillinger.

Under gjennomføring av Teaching Thinking-strategiene "En må ut" og "Kart fra minnet" viste studentene interesse og engasjement. Etter "Kart fra minnet" var studentene lydhøre for utdyping/ forklaring av figuren, og de umiddelbare tilbakemeldingene på opplegget var positive.

\section{Resultater fra spørreunders $\phi$ kelse}

Blant de 25 studentene som svarte på spørreundersøkelsen ( 20 kvinner og 5 menn) var det 6 som hadde en eller annen fordypning i naturfag fra videregående skole. Den formelle kompetansen for de fleste av studentene i utvalget er dermed naturfag fra videregående skoles grunnkurs (5-timers kurs). Tabell 2 viser frekvensfordeling for grad av tilslutning til utsagn i spørreskjemaet. Responsen på utsagn nr. 1 og 2 (tabell 2) viser at de fleste studenter i utvalget hevder at de alltid har likt naturfag, samt at de har fått et mer positivt forhold til naturfag i løpet av NSM-kurset. De utfyl- 
Tabell 1. Eksempler på situasjoner $i$ studenters rollespill som ledet fram til naturfaglige problemstillinger.

\begin{tabular}{ll}
\hline Situasjon i rollespill & Problemstilling som naturlig følger \\
\hline $\begin{array}{l}\text { Student i rolle "Rovdyret" sier at det må ha } \\
\text { nitrogenholdig mat for å få energi. }\end{array}$ & $\begin{array}{l}\text { Er proteiner livsviktige som energikilde, som } \\
\text { byggemateriale, eller som begge deler? }\end{array}$ \\
$\begin{array}{l}\text { Student omtalte nitrogenmolekyler i lufta som en } \\
\text { "nitrogenforbindelse". }\end{array}$ & $\begin{array}{l}\text { Sammenlign begrepene "nitrogengass" og } \\
\text { "nitrogenforbindelse". }\end{array}$ \\
$\begin{array}{l}\text { Et rollespill viser at nitrogenfikserende mikro- } \\
\text { organismer får tak i nitrogen og leverer dette til bjørka } \\
\text { (Betula pubescens). }\end{array}$ & $\begin{array}{l}\text { Hvilke arter planter og alger har samliv med } \\
\text { nitrogenfikserende mikroorganismer? (ikke B. }\end{array}$ \\
$\begin{array}{ll}\text { Et "dyr" i karbonsyklusen gjør tydelige miner av å } \\
\text { legge fra seg ekskrementer, for å vise at karbonet } \\
\text { sendes videre i syklusen }\end{array}$ & $\begin{array}{l}\text { Hvilke veier kan karbon forlate organismer? } \\
\text { I et rollespillet om nitrogensyklusen vises det hvordan }\end{array}$ \\
nitrogenet bringes videre ved at dyret dør og råtner \\
opp.
\end{tabular}$\quad$\begin{tabular}{l} 
Hvilke veier kan nitrogen forlate organismer? \\
\hline
\end{tabular}

lende tekstsvarene som begrunnet et mer positivt forhold til faget (fra 14 studenter) gikk i mange forskjellige retninger. Kun én student trakk fram "bruk av drama som metode", og ingen trakk frem TT-metodikk her.

Svarene på utsagn 3 og 4 (tabell 2) viser at de fleste av studentene mente det var greit å angripe nytt stoff med rollespill, og at det ikke var et problem at det ble mindre tid til strukturert forelesning. Kun tre studenter rapporterte at dette var problematisk.

Studentene var stort sett litt eller helt enige i at de husker/forstår fagstoff de framførte som rollespill bedre enn stoff som ble dekt med forelesning eller selvstudium, og at det å ha sett medstudenters rollespill var til hjelp i forhold til å huske fagstoffet (tabell 2, utsagn 5 og 6).

Tre studentene var helt eller litt enig i utsagnet "Jeg misliker å delta i rollespill" (utsagn 8, tabell 2). I deres svarskjema kan man se at to av dem likevel var blant de som var litt enig i at "rollespillstoffet" ble husket bedre enn forelest stoff, og at bruk av rollespill "brakte fagstoffet nærmere og 'tvang' meg til å gå mer inn i det enn jeg ellers ville gjort” (utsagnene 5 og 9 i tabell 2).

Sju studenter var litt eller helt enige i at eksemplene på rollefordelinger og replikker var overflødige eller kunne hemme kreativiteten. På den annen side var 18 studenter litt eller helt enige $\mathrm{i}$ at de samme eksemplene var klargjørende. De aller fleste studentene mente at det ikke var tilstrekkelig å bare bli fortalt om rollespill som metode, det var tvert i mot meningsfullt å bruke tid på å prøve dette ut. 22 sa seg helt enige $\mathrm{i}$ at gjennomføring av rollespill ga dem nye perspektiver på hvordan naturfaget kan formidles til elevene.

Av de ti som hadde minst ett års praksis som lærer var det fire som hadde brukt rollespill i naturfaglige sammenhenger. Til spørsmål knyttet til framtidig lærergjerning var det bare en som var litt uenig i at han/hun kommer til å benytte rollespill som arbeidsform i naturfagundervisninga. Det var få supplerende synspunkter, men jeg vil trekke fram ett: 
Tabell 2. Resultater fra spørreundersøkelse i en klasse på 36 lcererstudenter som deltok $i$ utprøving av rollespill og Teaching Thinking. Skjemaet ble besvart av 25 studenter (noen spørsmål ble bare besvart av 24 studenter).

\begin{tabular}{|c|c|c|c|c|}
\hline \multirow[t]{2}{*}{ Utsagn } & \multicolumn{3}{|c|}{$\begin{array}{l}\text { Grad av } \\
\text { tilslutning*: }\end{array}$} & \multirow[b]{2}{*}{4} \\
\hline & 1 & 2 & 3 & \\
\hline 1. Naturfag er et fag jeg alltid har likt. & 2 & 2 & 9 & 12 \\
\hline 2. I løpet av NSM-kurset har jeg fått en mer positiv holdning til naturfag. & 0 & 4 & 9 & 12 \\
\hline \multicolumn{5}{|l|}{ Bruk av rollespill } \\
\hline $\begin{array}{l}\text { 3. Vi burde ikke ha blitt satt til å lage rollespill om stoff som ikke var forelest } \\
\text { på forhånd. }\end{array}$ & 21 & 1 & 2 & 1 \\
\hline $\begin{array}{l}\text { 4. Ved å bruke tid på rollespill tapte vi tid som foreleser kunne brukt til å } \\
\text { legge fram fagstoffet på en klar og strukturert măte. }\end{array}$ & 21 & 2 & 1 & 1 \\
\hline $\begin{array}{l}\text { 5. Jeg husker/forstår det fagstoffet som vi framførte som rollespill bedre enn } \\
\text { stoff som ble dekt med forelesning eller selvstudium. }\end{array}$ & 1 & 1 & 13 & 9 \\
\hline $\begin{array}{l}\text { 6. Det at jeg så medstudenters rollespill hjelper meg å huske deler av } \\
\text { fagstoffet. }\end{array}$ & 1 & 1 & 13 & 10 \\
\hline $\begin{array}{l}\text { 7. Jeg husker at vi hadde rollespill, men det var ikke til hjelp i arbeidet med } \\
\text { å forstå/lære fagstoffet. }\end{array}$ & 15 & 7 & 2 & 1 \\
\hline 8. Jeg misliker å delta i rollespill. & 19 & 3 & 2 & 1 \\
\hline $\begin{array}{l}\text { 9. Bruk av rollespill brakte fagstoffet nærmere og 'tvang' meg til å gå mer } \\
\text { inn i det enn jeg ellers ville gjort. }\end{array}$ & 1 & 3 & 9 & 11 \\
\hline $\begin{array}{l}\text { 10. Eksemplene på rollefordeling og replikker var klargjørende for hvordan } \\
\text { et faglig rollespill kunne gjennomføres. }\end{array}$ & 1 & 5 & 7 & 11 \\
\hline $\begin{array}{l}\text { 11. Eksemplene på rollefordeling og replikker var overflødige (evt. ga } \\
\text { føringer som hemmet kreativiteten). }\end{array}$ & 9 & 8 & 6 & 1 \\
\hline $\begin{array}{l}\text { 12. Selv om rollespill er velegnet i grunnskolen, så er det ikke mening i at vi } \\
\text { lærerstudenter skal bruke tid på å gjennomføre dette i praksis på samlinger. }\end{array}$ & 20 & 2 & 2 & 1 \\
\hline $\begin{array}{l}\text { 13. Det at vi gjennomførte rollespill ga meg nye perspektiver på hvordan } \\
\text { naturfaget kan formidles til elevene. }\end{array}$ & 0 & 0 & 2 & 22 \\
\hline $\begin{array}{l}\text { 14. Rollespill er positivt fordi de gir variasjon i undervisninga, men utover } \\
\text { det har arbeidsformen liten betydning for min læring. }\end{array}$ & 12 & 5 & 6 & 2 \\
\hline $\begin{array}{l}\text { 15. Jeg regner med at jeg i framtiden vil bruke rollespill som arbeidsform i } \\
\text { min naturfagsundervisning. }\end{array}$ & 0 & 1 & 7 & 17 \\
\hline \multicolumn{5}{|l|}{ Teaching Thinking "En må ut" } \\
\hline $\begin{array}{l}\text { 16. "En må ut" om livet i fjæra var bortkastet tid, tradisjonell undervisning } \\
\text { ville gitt bedre utbytte. }\end{array}$ & 18 & 6 & 1 & 0 \\
\hline $\begin{array}{l}\text { 17. Jeg husker lite av fagstoffet som ble bearbeidet med "En må ut"- } \\
\text { opplegget. }\end{array}$ & 15 & 7 & 3 & 0 \\
\hline \multicolumn{5}{|l|}{ Teaching Thinking "Kart fra minnet" } \\
\hline $\begin{array}{l}\text { 18. Øvelsen der vi gruppevis skulle reprodusere en figur som vi fikk se på i } \\
10 \mathrm{~s} \text {. hver ("Kart fra minnet") hjalp meg å forstå hva som er avgjørende for } \\
\text { vekst av planteplankton i havet. }\end{array}$ & 2 & 6 & 9 & 7 \\
\hline $\begin{array}{l}\text { 19. Jeg er ikke i stand til å huske hva som var det faglige poenget med } \\
\text { denne øvelsen. }\end{array}$ & 9 & 8 & 6 & 1 \\
\hline $\begin{array}{l}\text { 20. Øvelsen var lite klargjørende og bør erstattes av en strukturert forklaring } \\
\text { av stoffet. }\end{array}$ & 10 & 9 & 4 & 1 \\
\hline $\begin{array}{l}\text { 21. Jeg kommer til å benytte Teaching Thinking-metodikk i min framtidige } \\
\text { naturfagundervisning. }\end{array}$ & 0 & 1 & 7 & 17 \\
\hline
\end{tabular}

*Grader av tilslutning: 1= Helt uenig, 2=Litt uenig, 3=Litt enig, 4 = Helt enig 
"Rollespill i naturfaget var loererikt, bare det å se at det var mulig var positivt, men det må ikke brukes for mye. Vi gjorde det en gang, $i$ løpet av et år ville det muligens ha voert nok med 2-3 ganger før interessen hadde voert borte. Når det gjelder bruken i barneskolen så gleder jeg meg til å bruke denne metoden, ikke minst for å kanskje gjøre faget mer attraktivt for jenter....."

Et stort flertall av studentene var positive til å bruke tid på TT-opplegget "En må ut", og de aller fleste var også var mer eller mindre uenig i at de husket lite av fagstoffet som ble bearbeidet med dette opplegget (tabell 2, utsagn 16 og 17). Flertallet av studentene var også positive til bruk av TT-opplegget "Kart fra minnet" om abiotiske faktorer og primærproduksjonen i havet. Alle så nær som én av de studentene regnet med å bruke TT- metodikk i sin framtidige naturfagundervisning. Åtte studenter hadde gitt utfyllende synspunkter om TT-metodikk (i forhold til både høgskole og grunnskole). Alle disse kommentarene var positive til bruken av TT-opplegg. Her vil jeg trekke fram et par:

-"Jeg har forsøkt TT i tverrfaglig i forbindelse med et undervisningsopplegg i 3. og 4. klasse. Det var en bra måte å innlcere nytt stoff, og ikke minst som repetisjon av gjennomgåtte temaer. Det var og en metode som disse ungene elsket. Tilbakemeldingene var at ungene i de resterende praksisukene til stadighet 'maset' om ikke vi kunne gjøre flere slike kartstafetter."

-"Den oppgaven vi skulle se i 10 s på arket ["kart fra minnet"-oppgaven] for så å tegne var utrolig bra, vi ble skjerpet, kampånden nådde oss og vi loerte noe."

\section{DRøFTING}

\section{Rollespill, Teaching Thinking og begrepsutvikling i naturfag}

Utprøvinga som her ble gjort viste at arbeid med korte faglige rollespill om økosystem og stoffkretsløp førte til gode anledninger for samtaler der faglige begrep ble utforsket og bearbeidet. Dette foregikk først mellom studentene i gruppene, så med faglærer i veiledning av gruppene, og deretter i plenum. Det siste skjedde med utgangspunkt i de oppfatninger og misoppfatninger som kom til syne i studentenes framføringer. Spørreundersøkelsen og egen opplevelse ga et positivt inntrykk av denne undervisningssituasjonen. Dette kan skyldes at rollespill krever personlig engasjement, at studentene fikk anledning til å være kreative, og at produksjon og framføringer utløser en del humor.

Rollespillene som er prøvd ut her kan sammenlignes med eksemplene fra Kvam med flere (1989) og Tveita (2003) på den måten at de i stor grad dreier seg om å illustrere materielle/mekaniske prosesser. Imidlertid ble det i denne utprøvinga lagt stor vekt på at deltagerne selv skal utforme replikker der de sier noe om hvilken rolle de har i det systemet som modelleres. Dette ble gjort for å stimulere gruppene til å ta i bruk faglige begreper. Det kan være et problem at elever vegrer seg for å framføre replikker for klassen. En mulighet er å la framføring for klassen være frivillig, slik at de som vegrer seg kan framføre sitt produkt for læreren. På den annen side må man kunne gå ut i fra at det er et generelt mål at elever etter hvert skal bli i stand til å presentere noe for sine medelever.

Begge Teaching Thinking-strategiene som ble utprøvd inneholdt et visst element av konkurranse. Dette så ut til å gi økt engasjementet i disse aktivitetene. Det kunne se ut som om konkurranseiveren førte til at studentene ble mindre opptatt av å skjule sine misoppfatninger slik at det ble lettere å justere disse. Kanskje kan også tilstedeværelsen av flere mulige løsninger gjøre det lettere å konsentrere seg om å fullføre selvstendige resonnementer, selv om man hører at andre har funnet et svar. 
Et sentralt og felles moment for arbeidsmåtene rollespill og Teaching Thinking er at de legger til rette for gruppevis kommunikasjon der studentene/elevene må bygge på sine egne forkunnskaper. Kommunikasjonen i gruppene vil automatisk tilpasse seg forkunnskapene, særlig hvis det ikke er alt for store nivåforskjeller. Disse arbeidsmåtene innebærer dermed en sosialkonstruktivistisk tilnærming. Vygótskij mente at all intellektuell utvikling og all tenkning har utgangspunkt i sosial aktivitet, og at språket er det viktigste redskapet for læring (Vygótskij \& Kozulin, 2001). Både rollespill og TT-metodikk kjennetegnes ved at elevene må snakke sammen i grupper om et gitt tema. Aktivitetene legger opp til at alle i gruppene må bidra ut fra eget nivå, forkunnskaper og formuleringsevne. Slik ivaretar disse arbeidsmåtene kravet om tilpasset opplæring. Hvis oppleggene forutsetter at elevene tilegner seg nytt stoff vil ofte noen på gruppene ha lettest for å tilegne seg dette, og disse elevene vil ta initiativ og bidra til å sette stoffet i en sammenheng som er meningsfull for resten av gruppa. Rollespill og TT-metodikk er etter min mening redskaper for å oppnå personlige involvering i lærestoffet. Når det gjaldt rollespill kunne lærerstudentene bekrefte at arbeidsformen brakte fagstoffet nærmere, og at de måtte gå mer inn i lærestoffet enn de gjør i andre undervisningssammenhenger.

\section{Arbeidsmåtenes egnethet for eksemplarisk undervisning av lærerstudenter}

Observasjoner i undervisninga og svarene fra spørreundersøkelsen tyder på at rollespill og Teaching Thinking hadde positive effekter på en gruppe lærerstudenters opplevelse av læringssituasjonen. Et begrenset utvalg og en moderat svarprosent innebærer at resultatene ikke gir grunnlag for bastante konklusjoner. Det er også naturlig å sette spørsmålstegn ved om utvalget er representativ for lærerstudenter i sin alminnelighet. Det kan jo være slik at studenter som unnlot å svare på naturfaglærerens (altså min) undersøkelse heller ikke er av de mest interesserte i faget. I utvalget var imidlertid et overveiende flertall positive til faget naturfag. Man kan stille spørsmålstegn ved dette, etter som realfagenes manglende popularitet jevnlig er i offentlighetens søkelys (se for eksempel Breivik, 2003). På den annen side poengterer Sjøberg (2004) at mange har stor interesse for naturvitenskap, problemet er bare at denne interessen ikke kommer til syne i form av fagvalg og studievalg.

Selv om det er viktig at lærerstudenter lærer om bruk av rollespill og TT-metodikk, og får eksempler på hvordan dette skal gjøres, så er det ikke dermed gitt at knapp undervisningstid bør brukes til å gjennomføre slike rollespill i praksis. Det er heller ikke gitt at alle grunnskolens arbeidsformer egner seg for bruk på høgskolenivå. I denne utprøvinga er det vist at rollespill og TT-metodikk kan tilpasses allmennlærerutdanningas naturfaglige innhold og nivå. I arbeidet med rollespillene var en god del av studentene noe frustrerte over at dette var nytt stoff. I følge spørreundersøkelsen i ettertid mente imidlertid de aller fleste at det var riktig å prioritere tid til å gjennomføre eksemplarisk undervisning, hvis alternativet var en mer strukturert gjennomgang av lærestoffet som skulle være tema for rollespillene.

\section{Hva formidles gjennom valg av arbeidsmåte?}

Det er en opplagt sammenheng mellom hva det er som skal læres og hva som skal til for å oppnå god læring. Hvis man endrer arbeidsmåtene i et fag, så vil man også uvilkårlig endre på hva som blir formidlet. Arbeidsmåtene som er beskrevet her har til felles at de ikke først og fremst etterlyser reproduksjon av naturvitenskapens begreper og sammenhenger. Studentene ble engasjert i problemstillinger der naturvitenskapen ga premisser, men ikke fasitsvar. Ved at studentene lærer å bruke denne type arbeidsmåter i naturfaget kan de i sin framtidige praksis formidle en mer levende og debatterende naturvitenskap. I spørreundersøkelsen sa de aller fleste studentene seg enige i at erfaringen med rollespill ga dem et nytt perspektiv på hvordan naturfag kan formidles. Sjøberg (2004) er opptatt av at skolens naturfag i stor grad beskjeftiger seg med å formidle etablert og allment akseptert fagstoff. Skolefaget får dermed preg av å formidle evige sannheter, og formidlingen kan dermed lett bli autoritær i formen. Sjøberg mener at det dermed formidles et falskt bilde av naturvitenskapens vesen, fordi naturvitenskapen egentlig er åpen, antiautoritær og kritisk. Hvis 
man skal dempe inntrykket av et autoritært fag vil det være viktig å bruke arbeidsformer der elever og studenter føler at deres synspunkter har betydning. De må få faget satt inn en sammenheng som fører til at de selv ønsker å vite hva vitenskapen mener å ha kommet fram til. En autoritet som forteller hva man må vite har ikke appell i dagens kultur. Knain (2001) fant i sin analyse av lærebøker at viktige deler av den naturvitenskapelige virksomheten ikke blir formidlet i naturfagbøkene. Elevene får ikke innsikt i forskernes debatter og gjensidige kritikk, og dermed unnlater faget å bidra til utvikling av elevenes kritiske sans.

Mennesker er forskjellige, og for noen kan nok naturfagets evne til å gi "fasitsvar" ha vært en del av fagets appell. Sjøberg (2004) antyder at skoleversjonen av naturvitenskapen, med sine trygge og sikre svar, kan gi inntrykk av å tilby et trygt sted for utrygge mennesker. Her vil jeg påpeke (og det er også Sjøbergs poeng) at faget har bruk for å rekruttere mennesker som stiller spørsmål ved oppleste fasitsvar. Evne til kritisk og uavhengig vurdering er uunnværlig i vitenskapelige sammenhenger. Derfor vil faget være tjent med å framstille seg på en annen måte. Samtidig ligger det i naturfagets vesen at man søker sannheten om den materielle verden rundt oss. Det ligger muligens en motsetning mellom det å søke Sannhet med stor S, og det å måtte innse at våre teoretiske modeller av omverdenen er et kulturprodukt, dog uten at vitenskapens teorier er uavhengige av en objektivt eksisterende virkelighet.

For å oppsummere resonnementet over: I hvilken grad faget betoner fasitsvarene kan ha betydning for hvilke mennesker som rekrutteres til faget, og det kan ha betydning for hvilket bilde allmennheten får av faget (Sjøberg, 2004). Det kan også ha betydning for hva som læres, fordi arbeidsmåter uten fasitsvar gir mer trening i resonnementer og meningsutveksling relatert til faginnholdet. Dette siste momentet må sees i sammenheng med hva man ønsker med faget; hva er fagets hensikt? Sjøberg (2004) har en utførlig gjennomgang av forskjellige mulige argumenter som kan rettferdiggjøre at alle bør lære noe om naturfag. Grovt sett vurderes fagets nytteverdi og dannelsesverdi. Han vurderer kompetanse i faget i forhold til vår nasjonale økonomi, enkeltpersonens inntektsmuligheter, hva som trengs for å klare seg i hverdagen, hva man bør vite om vår kultur, og hva som er nødvendig allmennkunnskap for at demokratiet skal fungere. Sjøberg har motforestillinger mot de fleste av argumentene for naturfag i grunnskolen. Alle trenger ikke lære seg naturfag selv om landet trenger spesialister. Det er ikke dokumentert god sammenheng mellom allmennkunnskapene i naturfag og et lands konkurranseevne. Mange oppnår god personlig inntekt og gjør strålende karriere uten å kunne mye om naturfag. For Sjøberg blir demokratiargumentet stående igjen som det viktigste (selv om han også der har nyanserende motforestillinger). Hvis valg av politiske ledere skal ha mening, "forutsetter det at vi som velgere er i stand til å skille bløff fra fakta, gode argumenter fra dårlige" (Sjøberg, 2004, s. 170). Og her kommer endelig mitt poeng: Hvis naturfaget i skolen har som sin viktigste oppgave å kvalifisere til den offentlige meningsutveksling, så må også undervisningen kvalifisere elevene til å komme med fagrelaterte og velfunderte meningsytringer. Skolen bør derfor legge vekt på arbeidsformer der elevene blir engasjerte i diskusjoner der naturvitenskapen kan være med på å levere premisser. Dette innebærer ikke å gå helt bort fra en systematisk tilnærming til deler av den etablerte vitenskap. Men som Ødegaard (2001b) observerte; når elevene blir emosjonelt og personlig engasjert, vil de selv etterspørre vitenskapens produkter på det aktuelle feltet. Man får da et bedre utgangspunkt for læring enn når læreren legger fram mengder av faginnhold og dikterer hvorfor dette er relevant for verden utenfor faget.

For all undervisning gjelder at det er behov for å ha variasjon i arbeidsmåtene, og alle arbeidsmåter har sine begrensninger. Jeg har ikke her tatt stilling til hvor stor plass rollespill og TT-metodikk bør ha i grunnskolen. Engasjementet kan trolig avta hvis for eksempel bruken av rollespill overdrives. Det kan også være vanskeligere å få elever i grunnskole eller videregående skole til å involvere seg like målrettet som voksne lærerstudenter, spesielt når det gjelder rollespill. Det er heller ikke like enkelt å anvende disse arbeidsmåtene til hva som helst av naturfaglig lærestoff. God planlegging kan sikre at forskjellige arbeidsmåter tas i bruk der de best kommer til sin rett. 


\section{KONKLUSJON}

En begrenset utprøving av arbeidsmåtene rollespill og Teaching Thinking i allmennlærerutdanninga viser at disse arbeidsmåtene kan tilpasses naturfaglig innhold, og at de gir gode betingelser for å jobbe med begrepsutvikling. En spørreundersøkelse blant de deltakende studentene tyder på at de har fått positive læringsopplevelser, noe som støtter bruk av disse arbeidsmåtene som eksemplarisk undervisning. Med tanke på å supplere tradisjonelle arbeidsmåter i naturfag er det spesielt viktig at arbeidsmåtene rollespill og Teaching Thinking stimulerer til engasjert faglig kommunikasjon, der elever kan bidra ut fra egne forutsetninger. Slik trening kan bidra til å kvalifisere elevene til å delta i den offentlige meningsutveksling, slik at de kan bli reelle deltakere i demokratiet. Rollespill og Teaching Thinking er derfor eksempler på arbeidsmåter som kan styrke naturfagets bidrag til det som bør være en viktig målsetting med all utdanning, nemlig målet om et sterkt demokrati.

\section{REFERANSER}

Almendingen, S. F., Klepaker T. \& Tveita J. (2003). Tenke det, ønske det, ville det med, men gjøre det...? - En evaluering av natur- og miljøfag etter Reform 97. Høgskolen i Nesnas skriftserie Nr 52. Høgskolen i Nesna.

Andersson, B. (1989). Grundskolans naturvetenskap: forskningsresultat och nya idéer. Stockholm: Utbildningsförlaget.

Berg, E. M. (2002). Hva skjer i tareskogen? Nedlastet 27.06 .2005 fra http://www.ttnor.no/tareskogen.html

Bjørshol, S. (1994). Rollespill som metode i engelskundervisningen. Oslo: Tano.

Bloom, B. (Ed.) (1956). Taxonomy of educational objectives: the classification of educational goals. Cognitive domain. New York: McKay.

Breivik, J. (2003). Til mediekamp for vitenskapen. Kronikk i Dagbladet 19.01.03.

Driver, R. (1983). The Pupil as Scientist? Milton Keynes: Open University Press.

Eide, O. S. (2002). Teaching Thinking i loererutdanningen - Noen erfaringer ved bruk av den didaktiske tilnoermingen Teaching Thinking $i$ et IKT- og samlingsbasert studium. HBO-notat 8/2002. Høgskolen i Bodø.

Imsen, G. (1999). Lcererens verden - Innføring i generell didaktikk. 2. utg. Oslo: Tano Aschehoug.

Knain, E. (2001). Naturfagets tause stemme. Diskursanalyse av loerebøker i Natur- og miljøfag. Oslo: Norsk sakprosa, Norsk faglitterær forfatter- og oversetterforening.

KUF (1996). Laereplanverket for den 10-årige grunnskolen. Oslo: Det kongelige kirke-, utdannings- og forskningsdepartement.

KUF (1999). Rammeplan og forskrift for 4-årig allmennloererutdanning. Oslo: Kirke-, utdanningsog forskningsdepartementet.

Kvam, A., Størkersen I. O. \& Valdermo, O. (1989). Metodisk veiledning i naturfag. Oslo: Rådet for videregående opplæring/Gyldendal Norsk Forlag.

Leat, D. \& Higgins, S. (2001). The Role of Powerful Pedagogical Strategies in Curriculum Development. Newcastle: Thinking Skills Research Group, Department of Education, University of Newcastle-upon-Tyne. Nedlastet 27.06.2005 fra http://www.ttnor.no/David-paper1.doc

Læringssenteret (n.d.). Metodiske veiledninger - Grunnkurs naturfag. Nedlastet 27.06.2005 fra http://skolenettet.ls.no/html/met/naturfag/

Mortimer, E. F. \& Scott, P. H. (2003). Meaning making in secondary science classrooms. Maidenhead: Open University Press.

Ringnes, V. \& Hannisdal, M. (2000). Kjemi i skolen - undervisning og loering. Kristiansand: Нøyskoleforlaget.

Sjøberg, S. (2004). Naturfag som allmenndannelse - en kritisk fagdidaktikk. (2. utg). Oslo: Gyl- 
dendal.

Sæbø, A. B. (2003). Drama i L97. I hvilken grad og hvordan er drama som fagområde og metode en del av innholdet og arbeidsmåtene $i$ grunnskolen? Program for Evaluering av Reform 97 Tema 1: Loereplanverket, fag og praktisk virksomhet. Stavanger: Høgskolen i Stavanger.

TT-NOR (2005). TT-NORs hjemmeside nedlastet 27.06.2005 fra http://www.ttnor.no/main.html Turmo, A. (1999). Praktiske aktiviteter i natur- og miljøfag. Bedre skole, 4, 66-70.

Tveita, J. (2003). Frå teori til praksis. Konstruktivistiske metodar i klasserommet (s. 213-225). I D. Jorde \& B. Bungum (Red.), Naturfagdidaktikk - Perspektiver, forskning, utvikling. Oslo: Gyldendal.

UFD (2005). Kunnskapsløftet - Loereplaner for gjennomgående fag i grunnskolen og videregående opploering. Loereplaner for grunnskolen. Midlertidig trykt utgave - september 2005. Oslo: Utdannings- og forskningsdepartementet.

Vygótskij, L. S. \& Kozulin, A. (2001). Tenkning og tale / Lev Vygótskij; revidert og redigert av Alex Kozulin. Oslo: Gyldendal akademisk.

Wellington, J. \& Osborne, J. (2001). Language and literacy in science education. Buckingham: Open University Press.

Ødegaard, M. (2001a). The drama of science education: how public understanding of biotechnology and drama as a learning activity may enhance a critical and inclusive science education. Series of dissertations submitted to the Faculty of Mathematics and Natural Sciences, University of Oslo; no. 115. Oslo: Unipub.

Ødegaard, M. (2001b). Dramatisk naturfag! Uddannelse, 5. Nedlastet 27.06.2005 fra http://udd. uvm.dk/200105/udd05-8.htm?menuid $=4515$ 